Article

\title{
Illicit Motherhood: Recrafting Postcolonial Feminist Resistance in Edna O'Brien's The Love Object and Jhumpa Lahiri's Hell-Heaven
}

\author{
Dibyadyuti Roy \\ Department of Communication, Indian Institute of Management Indore, Indore 45331, India; \\ dibyadyutir@iimidr.ac.in
}

Received: 21 November 2018; Accepted: 11 February 2019; Published: 14 February 2019

\begin{abstract}
Cultural constructions of passive motherhood, especially within domestic spaces, gained currency in India and Ireland due to their shared colonial history, as well as the influence of anti-colonial masculinist nationalism on the social imaginary of these two nations. However, beginning from the latter half of the nineteenth century, postcolonial literary voices have not only challenged the traditional gendering of public and private spaces but also interrogated docile constructions of womanhood, particularly essentialized representations of maternity. Domestic spaces have been critical narrative motifs in these postcolonial texts through simultaneously embodying patriarchal domination but also as sites where feminist resistance can be actualized by "transgress(ing) traditional views of ... the home, as a static immobile place of oppression". This paper, through a comparative analysis of maternal characters in Edna O'Brien's The Love Object and Jhumpa Lahiri's Hell-Heaven, argues that socially disapproved/illicit relationships in these two representative postcolonial Irish and Indian narratives function as matricentric feminist tactics that subvert limiting notions of both domestic spaces and gendered liminal postcolonial subjectivities. I highlight that within the context of male-centered colonial and nationalist literature, the trope of maternity configures the domestic-space as the "rightful place" for the existence of the feminine entity. Thus, when postcolonial feminist fiction reverses this tradition through constructing the "home and the female-body" as sites of possible resistance, it is a counter against dual oppression: both colonialism and patriarchy. My intervention further underscores the need for sustained conversations between the literary output of India and Ireland, within Postcolonial Literary Studies, with a particular acknowledgement for space and gender as pivotal categories in the "cultural analysis of empire".
\end{abstract}

Keywords: domestic; space; public; private; patriarchy; mother; postcolonial; India; Ireland

\section{Introduction}

In a poignant moment from Jhumpa Lahiri's short story Hell-Heaven, Usha, the narrator, describes the predicament of her mother, Aparna, an immigrant housewife living in 1970's America. As an educated woman from Calcutta, an urban metropolis in India, she was "even in her bleakest hours of homesickness ... grateful that my [Usha's] father [and Aparna's husband] had at least spared her a life in the stern house of her in-laws in the suburbs of Calcutta. On the other hand, it is this, a secure legacy of a traditional domestic space from India, devoid of her husband's apathetic neglect, as well as her alienated immigrant existence that she apparently yearns to bring back to Cambridge, Massachusetts, through her short-lived (and one-sided affair) with Pranab, a young Indian graduate student from Massachusetts Institute of Technology (MIT). What makes this romantic liaison unique is Aparna's (seemingly) maternal relationship with Pranab, a privileged and immature man-child from Calcutta who is unable to deal with living alone in America. Not unlike Aparna, Martha-the protagonist in 
Edna O'Brien's short story The Love Object-engages in sexual role-play with her lover that involves simulating the mother-child relationship with him, in her own house. At first glance, Martha and Aparna are vastly different: Martha is a successful and independent television announcer based in London and a single mother, as opposed to the domesticated mother, Aparna, who is economically dependent on her husband. However, beyond the surface appearance, the similarities start to become palpable. Aparna and Martha are both gendered postcolonial subjects, living in spaces away from their homelands and boxed within the traditional (social and maternal) roles that patriarchy prescribes for them with no opportunity of breaking out without inviting societal censure.

The collections of short stories from which these two narratives are drawn-Edna O'Brien's The Love Object (2013) spanning "the most celebrated of her mature short fictions" across five decades (Banville 2013), and Unaccustomed Earth (2004), Jhumpa Lahiri's second compendium of short fiction-while unique in their narrative fashioning also exhibit some remarkable similarities. Characters in multiple stories across both collections are often forced into "blindly supporting a mythologizing nationalism abroad" (D. O'Brien 2016, p. 6), which most often reinserts them back into the throes of "hegemonic, male-dominated power structures" (Lynch 1996, p. 37), ones they had presumably hoped to escape through migration. In both Edna O'Brien and Jhumpa Lahiri's writing, female figures are made to suffer due to the complacencies inherent in the male-biased public and private spaces they inhabit. Unsurprisingly, these women are also acutely aware that within these restrictive spaces, their male counterparts may possibly escape the consequences of an occasional misstep or indiscretion, but for them the situation is far direr. $\mathrm{O}^{\prime}$ Brien's fictional characters like Mrs. Reinhardt ("Mrs. Reinhardt") or the unnamed female narrator in "Paradise," "have been in their different ways, betrayed by men and men's impossible expectations of what and how they should be" (my emphasis; Banville 2013) find clear parallels in Lahiri's female protagonists. For example, the young immigrant career woman, Ruma, in the title story "Unaccustomed Earth," who constantly strives to match the societal expectations of being a dutiful daughter, wife and mother, or Sudha in "Only Goodness," who irrationally sees herself responsible for the alcoholism of her brother, as well as the consequent breakdown of their sibling relationship. While, the limitations of space do not permit a full-fledged investigation of these fascinating characters across the literary spectrum of two distinguished authors, I have chosen to focus on two representative short stories that typify how "writing plays a concrete as well as metaphorical role in the psychological dynamics of diaspora space" (Murray 2013, p. 84). My analysis juxtaposes Edna O'Brien's treatment of non-normative liaisons in "The Love Object" with Jhumpa Lahiri's chronicling of the gendered immigrant experience in "Hell-Heaven" to argue for the tactical value of illicit motherhood in subverting monolithic and strategic constructions of womanhood. Further, in dissecting the theme of societally disapproved relationships, which recur in numerous postcolonial feminist narratives, I foreground the importance of matricentric feminism in challenging the essentialized masculinist legacy of domestic spaces, as well as the bodies that inhabit them

This article underscores that characters like Martha and Aparna, and indeed many others in Lahiri and O'Brien's oeuvre, are synecdochic figures who represent the liminality of female postcolonial bodies everywhere, and constantly negotiate patriarchy, and imperialism alongside the troubling legacies of "mother(land), diaspora and belonging" (Murray 2013, p. 85). My intervention here builds on existing scholarship in both the social sciences and the humanities where an analysis of migrant identities attempts to move beyond insular and/or individual migrant narratives toward the critical paradigm of the "diaspora space" (Brah 1996) where "multiple subject positions are juxtaposed, contested, proclaimed or disavowed; where the permitted and the prohibited perpetually interrogate; and where the accepted and the transgressive imperceptibly intermingle" (Brah 1996, p. 208). By putting Lahiri and $O^{\prime} B$ Brien into conversation, I interrogate the partisan approach that pervades much of postcolonial literary women's studies, where focused transnational comparative analyses are often occluded in favor of narrower critical analyses that only summarize the specificities of a single author and her oeuvre. Further, in bringing together Lahiri and O'Brien's work under the 
epistemic paradigm of the "diaspora space," I simultaneously emphasize that narratives can become "a symbolic space of intersubjective communication ... to explain relationships which are articulated in different historical periods, in different socioeconomic and cultural contexts" (Giorgio 2002).

For O'Brien, who has been termed as "the Solzhenitsyn of Irish life" since she is one of "the [only] ones who kept speaking when everyone else stopped talking about being an Irish woman" (Wigfall 2014), her narratives represent a distinctive tradition in Irish literary studies, where the historical and factual elements of Irish female subjectivity become interspersed with the challenges, constraints, and aspirations of her fictional characters. Following in the illustrious footprint of Mary Ann Sadlier, Kate O'Brien, and Mary Lavin, as well as inspiring recent Irish writers like Nuala Ní Chonchúir, Anne Enright, and Emma Donoghue, Edna O’Brien arguably stands as the primary mediating artist-activist who fuses together historical insights about Irish migration with contemporary critiques on traditional gender roles, femininity, and motherhood. O'Brien's female characters like Kate Brady (Girls in Their Married Bliss, O'Brien 1964), Willa McCord (Casualties of Peace, O'Brien 1966), or Mary McNamara (Down by the River, O'Brien 1996) exemplify the tussle between public and private spaces through the "shifts in perspective and identity that take place in ... the characters' lives between Ireland and elsewhere" (Murray 2013, p. 86). These characters, of course, are deeply rooted in O'Brien's own experiences (and frustrations) with her country of origin. In a recent interview with Sinead O'Shea, after the publication of her latest novel The Little Red Chairs (E. O'Brien 2016), O'Brien reiterated that Ireland indeed has been the locus of her creative output, and as John Banville notes, "although she left it [Ireland] early she is never far from the world she was born and where she was brought up" (The Love Object). Much like Jhumpa Lahiri, a Pulitzer-Prize-winning, second-generation, American-Bengali immigrant from India, Edna O'Brien's narratives have had “[M]igration ... as a persistent presence ... since she first began writing in the 1950's" (Murray 2013, p. 85). In fact, even though migration may not be explicitly visible in O'Brien's writing, "[t]he lives of many of her female protagonists are profoundly affected by it ... [and their] traumatic personal experiences in Ireland which usually result in a desire to escape." (Murray 2013, p. 85). Lahiri, on the other hand, belongs to a unique authorial space; unlike other Indian women, English writers—such as Anita Desai, Bharati Mukherjee, and Chitra Banerjee Divakaruni-who were born and spent their formative years in India, Lahiri's narratives are inspired by the connection she shares with India as the daughter of immigrant parents. Critics note that Lahiri's particular efficacy in capturing the gendered immigrant experience could be attributed to her "own longing to find her belonging in the maze of cultural alienation" (Priyadarshini 2016, p. 52). Her debut collection of short-stories, The Interpreter of Maladies (1999), which won the Pulitzer Prize for Fiction introduced South Asian immigrant characters in a new light, especially women figures who were caught in a twilight zone where migration and motherhood intersected to reinforce patriarchy in both public and private spaces. The Interpreter of Maladies abounds with what is termed as the "postcolonial dilemma" where "immigrants struggle to maintain their identities while trying to shake them off at the same time" (Lamture 2017, p. 803). The subtitle of Lahiri's debut fiction collection is "Bengal, Boston and Beyond," and effectively emphasizes the alterity of the gendered migrant, who cannot be tied to one or even two spaces since their identity is always beyond normative characterizations of spatial recognition. Consequently, the problematics of identity and migration that lead to new possibilities and frictions are a hallmark of Lahiri's writing. Her second collection, Unaccustomed Earth, maintains this attribute while developing characters who provide further nuance to this intricate condition. I emphasize here that while the positionalities of Lahiri and O'Brien may differ, especially in reference to the countries that form the basis of their work, the "narrative identity" inhabiting their writing, as well as those of their characters, is a direct response to historical events and ideologies, which have permeated the authors' lives (Pearce and O'Brien 1996). My analysis in the following sections underscores the need for sustained conversations between the artistic output of India and Ireland within Postcolonial Studies, along with a particular acknowledgement of space and gender as pivotal categories in the "cultural analysis of empire" (Nolan 2007) and within the domain of matricentric 
feminism (O'Reilly 2015), which looks at the "feminism developed from the specific needs/concerns of mothers" (ibid.) and has found little valence in traditional Women's Studies scholarship.

\section{Motherhood and Nationalism}

Domestic spaces, functioning historically under a patriarchal signifying system, have maintained a distinct binary between the public and the private, while reinforcing "men's power advantage" (Szczygiel 2003). In the context of literary productions, such dualistic divisions of public spaces as masculine and private spaces as feminine (Landes 1998) found a particularly explicit expression in 19th century fiction (specifically in novels), propagating a gendered bias that finds reflection even in contemporary fiction. The introduction of postcolonial voices in the literary sphere initiated during the late 19th and early 20th century, however, saw such rigid definitions of the public and the private being increasingly challenged. Through simultaneously embodying the potential for patriarchal strategic domination as well as feminist tactical resistance, domestic spaces started becoming more fluid sites. Unsurprisingly, a large section of postcolonial fiction sees domestic sites as critical narrative motifs that "transgress traditional views of the domestic landscape such as the home, as a static immobile place of oppression" (my emphasis; Dowler and Szczygiel 2006). As my analysis here demonstrates, domestic landscapes function in postcolonial feminist fiction as fertile territory for critiquing metanarratives about nation, space, and gender through providing microcosmic representations of the constant dialectic, which ensues between the oppressor and the oppressed in the macrocosmic world.

To understand the significance of non-normative relationships in such domestic spaces, as modes of matricentric feminist resistance, it is vital to trace the history of women as maternal symbols in postcolonial spaces, such as Ireland and India, especially their relation to the processes of both colonialism and nationalism. In Spivak's words, if the colonialists were always already involved in "white men saving brown women from brown men" (Spivak 1988), thereby projecting colonized women as constantly subjugated, the indigenous nationalists further consolidated this metaphor by sidelining women in the nationalist project. Irrespective of the actual role of women in nationalist movements, female bodies were constructed as passive bystanders in the fight against colonialism. Tropes, such as "Mother Ireland" and "Mother India," developed through a masculine nationalist ideology implied that women were merely maternal icons, for whom brave men "were willing to lay down their lives" (Butalia 1996, para. 9). Unfortunately, anti-colonial nationalism, particularly in India and Ireland, reappropriated the trope of maternity from the colonialists, only to use it as a mode of supporting reductive (and masculine) constructs of nationhood.

In the context of male-centered colonial and nationalist literature, it needs to be underscored how the trope of maternity is linked directly to the domestic space as the rightful place for the existence of the female body. The female body representing the "honor and virtue of the nation" (Butalia 1996) was constructed in anti-colonial discourses as a sanctified entity who needed to preserve her modesty and chastity in order to conform to the patriarchal nationalist ideology. This construction of "femininity" as a singular monolithic ideal through a male-biased lens meant that women were supposed to suppress their emotions, their sexuality, and any other characteristics that were non-conformant to patriarchal assumptions. As a striking parallel, Clíona Ó Gallchoir notes "Irish identity which prevails and has prevailed since the nineteenth century is based on a fixation with the construction of [female] identity in a national public sphere and thus on masculinity as a norm" (Nolan 2007). Similarly in India, "there are so few studies of women's role in the nationalist movement ... and the lives and conditions of the large majority of women ... have consistently been unexplored and marginalized in history" (Kasturi and Mazumdar 1994). In fact, conceptualizing the postcolonial nation-state in both Ireland and India has been heavily influenced by a patriarchal value system, which automatically discards multiplicitous notions of womanhood or femininities (Connell and Messerschmidt 2005) in favor of a single sanctified version that suits the political goals of male nationalists. Thus, when postcolonial feminist fiction reverses this tradition through constructing the "home and the female-body" (Kuttainen 2009) as sites of possible resistance, it is a counter against dual 
oppression: both colonialism and patriarchy. Considering that both India and Ireland were colonies of Britain and had analogous reactions against the processes of colonialism ${ }^{1}$, it is surprising to note the dearth of comparative cultural scholarship. Thapar-Björkert and Ryan note, "British rule did not simply bring Indian and Irish people into the empire; it also provoked very similar reactions in both countries, especially in terms of cultural nationalism and militant nationalist movements" (Thapar-Björkert and Ryan 2002). Therefore, this paper arising from an interest in perceiving non-normative constructions of motherhood in the fiction of Edna O'Brien and Jhumpa Lahiri also makes an attempt to bridge the substantial lacuna that exists in this sphere. Consequently, my analysis demonstrates how a matricentric feminist approach allows the female protagonists in these two representative stories to gain agency both inside and beyond postcolonial domestic domains.

Constructions of passive maternity against which O'Brien and Lahiri create counternarratives directly challenge "[the] trope of maternity ... called upon in the service of a national bildungsroman; the maternal [that] figured as a site which allegorized the natural development of a fertile colony laboring to deliver an independent nation and modernity" (Kuttainen 2009). Specifically in reference to Ireland, it is important to underscore the challenge for Irish women to counter masculine nationalism, since in the post-famine period, feminist agency had been greatly undermined by their weak economic status. Daly notes that:

Farmers' daughters who worked as laborers and unpaid servants in their own homes, as well as farmers wives, were all recorded as 'inactive' in the census of the period. Precisely in these unpaid, unwaged, invisible economic activities, we find the epitome of the subordinated status of 19th century Irishwomen. (qtd. in Jackson 1984)

The land scarcity that resulted due to the famine also contributed to the commodification of women since arranged marriages came into vogue replacing the "earlier more spontaneous customs" (Jackson 1984). In these marriages, women came to be identified as transferable items who were married to the most prosperous landowner and led to substantial financial gains for the bride's family. Therefore, in order to escape this economic rut, most women were forced to conform to the ideals of a "bourgeois Catholic nation" (Ó Gallchoir 2005) that was being constructed largely through patriarchal nationalism. Concurrent with the economic commodification of women that was undertaken in the "bourgeois Catholic" Irish state, the late 19th century also saw the addition of Mariolatry to the official state decree that "heralded the final achievement of patriarchy and Catholicism" (Pelan 1993). Mariolatry, which was implemented through the Immaculate Conception of 1854, exonerated the figure of Mary from any sexual or carnal implications. ${ }^{2}$ The trope of submissive motherhood that had been reified through the ideology of Mariolatry, implied female subjectivities had been completely subsumed by the norms of a despotic masculinity. Such a dominating patriarchal framework grounding itself in the late 19th century gained considerable momentum in the late 20th century, the period during which Edna O'Brien produced much of her literary works. In developing a chronological progression, the following section discusses Edna O Brien's "The Love Object" and sets up the framework for a comparative analysis of Lahiri's "Hell-Heaven" in the next section.

1 Thapar-Björkert and Ryan note: (.. ) at the time when nationalist movements were gaining influence in both countries, there were significant similarities and points of contact between nationalist activists and cultural leaders. These links so often took the form of personal friendship and direct communication. For example, the Irish poet and one of the leaders of the cultural nationalist movement W. B. Yeats, was greatly influenced by his friendship with the Indian writer Rabindranath Tagore (Kelleher 2013). The Irish suffragist leader Gretta Cousins, cofounder of the Irish Women's Franchise League, spent many years living and working in India (Thapar-Björkert and Ryan 2002, p. 302).

2 As Pelan notes: Mariolatry imposed on women a dilemma that is unsolvable: to follow Mary and remain pure, which involves a renunciation not only of sex but of motherhood, or to marry and bear children and thus, be reduced to the sensuality and baseness of Eve. The church's answer to this dilemma has been to teach purity and chastity until marriage, at which time sex, for purposes of procreation only, becomes a duty devoid of sin, but a duty nonetheless ... While the Cult of Mary may have suited the romantic vision of a pure and wholesome Ireland, it has been extremely damaging for Irish women, since not only is it a totally unattainable ideal, but, in Simone de Beauvoir's terms, represents, "the supreme masculine victory" (my emphases; Pelan 1993, p. 59). 


\section{3. "Search for Their Identity in a Sexually Repressed Ireland": Edna O'Brien's The Love Object}

Private spaces occur as dominant settings in the short stories of Edna O'Brien, where O'Brien's protagonists are found to "desperately search for their identity in a sexually repressed Ireland" (Pearce 2006). O'Brien's narratives have faced considerable detraction and have been "attacked for her frank treatment of sexuality and alleged sensationalism" (Colletta and O'Connor 2006). The themes of adultery and illicit relationships that form recurrent tropes in her work have been mostly interpreted as signifying the subservient position of Irish women under a patriarchal hegemony. However, such critical appraisals of O'Brien's oeuvre seem to essentialize the concept of feminine resistance by locating illicit relationships merely as patriarchal markers of power over the female body and thereby ignoring the counter-hegemonic possibilities implicit in non-normative relationships. It becomes important here to underscore the epistemic problem inherent behind such assessments of Edna O'Brien's novels and in fact with most contemporary scholarly criticism about novels. Many literary theorists who are concerned with "pursuing ethics and estimating literary value in the light of and in response to complex and difficult poststructuralist truths" (Hale 2009, p. 809) often categorize literary works as a "moral collective" (ibid.), predicated on the idealized aesthetics of a normative societal framework. It is no wonder, therefore, that women artist-activists, especially from postcolonial nations, who are located in the fissures and write in opposition to "nineteenth-century white male writers" (Hale 2009, p. 810) are found wanting by both reading publics and critics in reference to existing literary standards.

O'Brien's literary output was initially met with "scandalized outrage in her native country" due to her "frank portrayal of female sexuality, a subject considered by Irish censors to be pornographic and obscene" (Colletta and O'Connor 2006). What is striking about O'Brien's oeuvre is her deconstruction of the patriarchal construction of motherhood and the challenging of the idealized mother figure who was supposed to be revered and worshipped. In her story "The Love Object," the protagonist Martha, a television announcer, has as her "love object" a famous lawyer who is "Elderly. Blue eyes. Khaki hair $(\ldots)^{\prime \prime}$ and with whom she unabashedly goes to bed with, on their first night of interaction. The sexual encounter takes place in Martha's house, a domestic space usually connoted in Irish literary tradition to be a sacrosanct institution, codified through values of fidelity, Catholicism, and passive motherhood. In contrast, Martha's household has very little evidence of conventional femininity or motherhood and is acknowledged only in passing when the lawyer asks for some sticking plaster the next morning. Martha replies in a straightforward manner that "There is no plaster left," acutely aware that even though she might be construed as "neglectful" she did not need to justify her lack of an organized household, a caring (maternal) instinct or "why my sons were at boarding school, when they were so young." (O'Brien 1984, p. 149). In fact, she emphatically states "But I didn't," an indication that she is not in need of patronizing sympathy from a stranger, who is himself in his third marriage, and like her, also willing to engage in a casual one-night stand. Martha decisively notes the role of the lawyer as a stand-in or temporary replacement for her two children who she "missed badly and longed to hold ... in my arms-another reason why I welcomed him (the lawyer)" (ibid., p. 150). Contextually, Rebecca Pelan perceives O'Brien's writing as "a mission to expose the brutality of various insidious forms of oppression, best seen in her undermining of the conventional patriarchal family and in her portrayal of how women are affected by being apart from themselves and each other" (Pelan 1993). Martha is denied the chance to parent her children by her ex-husband who forcibly sends them off to boarding school and the act of parenting for Martha must therefore be understood beyond the mere essentialized association of the mother, as a care-giver, for her children. For Martha, parenting is her decreed ontological right as the biological mother, a role she is clearly willing to be invested in (but on her own terms) until it is taken away from her by her former husband. Martha's actions reflects Pelan's argument about patriarchy denying women agency through disassociating them from other women and reflects the larger world of female characters in Edna O'Brien's short fiction like Maisie in "Brother" or Ita McNamara in "Oft in the Stilly Night," all of whom have been "in some way damaged by the world, and specifically the world of men" (Banville 2013), and in Martha's case, her children whom she considers an extension of herself. Significantly, such agency derived from 
single-parenthood is not predicated on the binary structure of the "powerful" independent father and "powerless" submissive mother through which patriarchy functions in this narrative and elsewhere. Rather it is a multiplicitous model where patriarchal power is deconstructed through non-traditional acts of maternity such as parenting as a single mother, unencumbered by the reductive demands of stereotypical womanhood.

Martha's ideological moorings are in matricentric feminism that illustrate how "many of the problems mothers face-socially, economically, politically, culturally, psychologically and so forth-are specific to women's role and identity as mothers" (O'Reilly 2015). This makes her acutely conscious that patriarchal structures within which she is embedded want to brand her as a "failed" mother, thereby paradoxically denying that her so-called failed motherhood is a direct result of these patriarchal constructs. In this case, this primarily happens through the character of her ex-husband who "insisted on boarding school" so as to "deprive me (Martha) of the pleasure of their (the children's) company" (O'Brien 1984, p. 149). In fact, her all-encompassing love patterns indicate that she is invested with the qualities of compassion and sensitivity, considered to be the prerequisites of being an excellent maternal figure by the masculine culture within which she is located. This is exactly why Martha requires a "love object": to escape the vicious demands of being a mere maternal archetype. Therefore, she chooses to challenge monolithic constructions of femininity and attempts to reclaim herself, as well as motherhood, on her own terms. Critics, such as Kiera O'Hara, have opined that the narrator's possessiveness with her "love object" is completely one-sided and highlights "obsession or addiction than ... love" (O'Hara 1993). O'Hara, however, misses a critical point in this short story, which is that even though Martha was willing to have a casual liaison with the lawyer, it is the lover who initiates contact "two mornings later ... and asked [if] was there a chance of our meeting that night" (O'Brien 1984, p. 149). Furthermore, Martha is willing to accept an open (non-exclusive) relationship, but it is in fact her male lover who forces her into guilt by turning up "unexpectedly" as she was preparing to go "to the theater with another man" (O'Brien 1984, p. 151). From the textual evidence, it can be asserted with authority that Martha's relationship with her lover does not deprive her of agency, but in fact provides her multiple opportunities to subvert idealized heterosexual relationships and thereby hegemonic patriarchy.

She sees in her "love object" an Oedipal lack that the lover desperately needs fulfilled. Reciprocally, Martha locates in this societally disapproved relationship a potential filler for the lack embedded in her: the unfulfilled performances of motherhood bereft of patriarchal constraints. Throughout the narrative are strewn examples of the mother-child relationship that Martha enacts with her lover. She does "most of the loving" (O'Brien 1984, p. 154), squeezes out orange juice for him before he leaves and fastens his trousers with her own safety pins. In the "most intimate of all our intimate moments," Martha allows her lover to perform a childhood fantasy as she leads him "across the goatskin and laid him down," allowing him to suckle on her. This is a scene where Martha has attained a clear sense of matricentric feminist agency that is independent from passive constructs of Irish motherhood. Carnal sexual instincts have been situated alongside a filial bond as the narrator asserts "He was not my father, I became his mother ... Even my nipples, about which I am squeamish, did not shrink from his rabid demands. I wanted to do anything for him" (O'Brien 1984, p. 152). This conflation of the sexual and the maternal is vital for $\mathrm{O}^{\prime}$ Brien in deconstructing the passivity associated with Irish motherhood and simultaneously this "eroticism and sexuality [act] as means of expressing individual and artistic liberty in the face of conservative socio-political structures imposed on Irish writers of her time" (Pelan 1993). Ironically, it is through Martha-a name deriving from the Aramaic for "mistress," which is antithetical to both the character of the mother in the Biblical tradition and the ideological constructions of motherhood in Mariolatry-that Edna O'Brien deconstructs the passive constructions of motherhood. She speaks of this earlier tradition of motherhood in her non-fiction piece Mother Ireland:

Mothers worked and worried and sacrificed and had the smallest amount on their plates when the Family sat down to eat, mothers wore aprons and slaved and mothers went to the 
confraternity on a Sunday evening and whispered things to each other in the chapel grounds about their wombs and their woes. (O'Brien 1984, p. 50)

Martha, in contrast, is a far cry from this asexual de-gendered construction of motherhood valorized by the Cult of Mary in Catholic Ireland; she is an award-winning successful television announcer who has men "kiss (her) on my back" (O'Brien 1984, p. 158) at parties and has a voracious sexual appetite. She is an individual who considers a "stranger and a lover" as the "ideal bed partner" and caresses and comforts her lover to "consolidate her ownership" (O'Brien 1984, p. 160) of them. Martha actively fights against reductive notions that "once a woman has a baby, the egalitarian office party is over" (Crittenden 2010, p. 88), which try to constrict women, especially mothers, into stifling positionalities. Significantly, considering the period of O'Brien's writing, where sexual activity for the woman was deemed fit only for the purposes of procreation, Martha is both literally and figuratively an iconoclastic figure. In Martha, an economically independent migrant career-woman who is unabashed about her desires and sexuality, $\mathrm{O}^{\prime}$ Brien conflates sexual independence and maternal instincts within the diaspora space, asserting that they are not diametrical opposites (as constructed by patriarchy) and can co-exist in a single subjectivity.

An important transition takes place in this story as Martha's lover decides to terminate their relationship with a casual "I adore you but I'm not in love with you; with my commitments I do not think I could be in love with anyone" (O'Brien 1984, p. 160). Kiera O'Hara notes that Martha's disturbed mental state and her suicidal attempt following this incident all point out to "the narrator's obsessiveness" (O'Hara 1993) with her "love object." Unfortunately, O'Hara's assessment of Martha's character is highly limited since Martha is constructed by $\mathrm{O}^{\prime} \mathrm{Hara}$ as a helpless victim who has been exploited by patriarchy. Although Martha is indeed a victim of patriarchy, what $\mathrm{O}^{\prime}$ Hara misses is Martha's active resistance against such structures. In fact, as Rachel Lynch notes "many of Edna O'Brien's short stories ... concern themselves with an often graphic exploration of women's coping strategies, most of which are activated ... as desperate measures" (Lynch 1996, p. 38), and most of them are tactical methods to service matriarchy. For example, Mary, the protagonist in O'Brien's "Irish Revel" manages to evade an attempted rape on her at a party by the village lout, O'Toole, through an act of female bonding. Interestingly, the female figures who support her are "Doris, Crystal, and Eithne, the town girls" (ibid.) with whom Mary does not share a particular rapport but does find support from in a moment of crisis. Such acts of strategic essentialism abound in O'Brien's fiction; it is therefore not a coincidence that $O^{\prime} B$ rien's story is titled "The Love Object," since it is reverses patriarchy's usual objectification of women. As the narrative progresses it becomes clear that it is Martha who from the very first meeting has commoditized her lover as an "object," through which she can fulfill her unrequited maternal instincts, denied by patriarchy. Her apparent panic at her lover's rejection of her is not due to her "obsessiveness" but rather her emotional breakdown at losing the only "object" through which she could enact her unfulfilled maternal performance. This aspect of her personality is justified when she gradually regains her composure and sense of selfhood through her interaction and nursing of her two biological children. The processes of recuperation are highlighted in the narrative as she sits in a bus and notices an advertisement that poignantly notes "DON'T PANIC. WE MEND, WE ADAPT, WE REMODEL" (O'Brien 1984, p. 169), externalizing Martha's internal workings. The void forcibly created in Martha's life through the absence of her children had been compensated for by her by the presence of the "love object": the lawyer and lover.

Allowed to perform maternal bonds with her biological children who are now back on a break from boarding school, Martha regains normalcy. Martha is now indeed more secure in her identity, as a woman and mother that are no longer discrete categories, since her maternal care-giving is on her own terms and not predicated on societal demands. During one of the first interactions between mother and child in the story, as Martha undresses her young son (much in the manner of how she used to undress her lover) she comments: 
It was strange and unsatisfying to hold him in my arms, when over the months I had got used to my lover's size ... which obliged me to stand on tiptoe so that our limbs could correspond perfectly ... Holding my son, I was conscious only of how small he was and how tenaciously he clung. (O'Brien 1984, p. 167)

This is a moment of monumental narrative importance as it underscores both the reversal of the heteronormative power dynamic as well as an active realization for Martha of her new-found agency. Her "strange and unsatisfying" feeling at holding her child mirrors her first interaction with the lawyer who was also a "stranger" before he became her lover. But at that point, she was the one "tenaciously" clinging on to the "love object" as the only site through which she could regain her maternal agency. Now, Martha empowered by matricentric feminism, has radically altered her liminal status: the onus is now on the male child to fulfill his mother. As the weeks pass by, Martha derives an increasing sense of "satisfaction" from performing maternal care-giving acts with her children, allowing her to "think less harshly of him (her lover)," since she consciously realizes the role of her former lover: a mere "object" allowing her to resist limiting notions of motherhood and femininity. Toward the end of the story, Martha's recognition becomes explicit as she comments:

I thought of him and my children in the same instant, their little foibles became his: my children telling me elaborate lies about their sporting feats, his slight puffing when we climbed steps and his trying to conceal it. (O'Brien 1984, p. 170)

At the beginning of "The Love Object," Edna O'Brien's protagonist is a victimized woman who is being oppressed through the emissaries of patriarchal domination: a scheming ex-spouse who refuses to allow her time with her children and an apparently dominating lover who exploits her for physical bliss. But by the end of the narrative, not only has Martha managed to subvert the strategies of patriarchy (de Certeau 2008) by constructing motherhood on her own terms, she has paradoxically done so by objectifying a successful and powerful patriarch as her "love object," most notably within the very domestic spaces that have been located in Irish socio-economic discourses as sites of oppressed womanhood.

One of the problems associated with feminist fiction of the modernist period is that it modeled the experience of the white Western woman as the framework through which every other female identity should be understood. Postcolonial feminist fiction functions as an important counterpoint to this homogenization of feminine experience by chronicling the experiences of women from diverse walks of life. Edna O'Brien's construction of femininity is particularly striking in this regard considering that her female characters do not cater to a singular mode of domesticity. While retaining the modernist focus on the quotidian, O'Brien retraces maternity through characters that transgress accepted Eurocentric/colonialist notions of the "home-maker": the mothers in her stories are often career-women or at least individuals who have the potential to assume a vocation beyond the domestic. Edna O'Brien's shorty story "The Love Object," composed around 1968, was produced in the heyday of second wave Anglo-American feminism, when concepts like motherhood and maternity were being considered regressive towards an emancipatory feminist praxis. O'Brien's construction of motherhood in "The Love Object" functions as a direct counter to both the passive constructions of maternity transcribed by patriarchy as well as by the (often problematic) second wave (white) feminist conceptions of motherhood. By rejecting such reductive constructions, Martha in "The Love Object," like many of the other female characters in O'Brien's short stories, promises the possibility of a dynamic postcolonial womanhood: one that is constantly in flux and not tied down to spatial and gendered stereotypes.

\section{4. “A Place to Regain Lost Perspective, Give Life New Meaning": Jhumpa Lahiri's Hell-Heaven}

In an August 2017 interview with the Literary Hub, Jhumpa Lahiri-who shortly after the publication of her last English novel, The Lowland (2013) decided to move to Italy and write in Italian - when asked about the sudden need for migration claims: 
"A sense of frustration, of dissatisfaction. I used to look for an identity that could be sharp, acceptable, mine. But now the idea of a precise identity seems a trap, and I prefer an overabundant one: the Italian piece, the Brooklyn one, the Indian one. Identity is a completely fluid thing, and metamorphosis has this concept in it". (Francesca 2017)

It is therefore not surprising that Edna O'Brien's ideological leanings and indeed her frustrations at boxed identity categories are paralleled in the short fiction and novels of the postcolonial Indian-American novelist Jhumpa Lahiri. Many of Lahiri's protagonists inhabit the time frame that Edna O'Brien writes during and she shares with O'Brien a love for exploring the politics of gender in enclosed domestic spaces. Born to Indian (Bengali) immigrant parents in London and then raised in the United States, many of Lahiri's protagonists are immigrants themselves who have been transported from their homeland India to alien lands. But their existence in both spaces is circumscribed by the norms of patriarchy and whiteness. Importantly, like O'Brien who chronicles the trials and tribulations of middle class and lower middle class Irish women, Lahiri's protagonists derive primarily from working class or lower-middle class backgrounds who have now been transposed into a different social, economic, and cultural setting. Such a specific class context in the writings of both these authors become highly significant in view of the postcolonial angle: since in colonial literature, the few women characters who have been discussed have mostly belonged to the "elite sections of society" (Kasturi and Mazumdar 1994). Lahiri's effective use of narrative tropes is consistent across her short story collections: the unfaithful husband ("A Choice of Accommodations" and "The Interpreter of Maladies") or confused South Asian immigrant children ("Sexy" and "When Mr. Pirzada Came to Dine"), although none of the treatment is similar. The disloyalty of spouses or confusion of first-generation immigrant children is uniquely articulated and "offers a balanced representation that helps her reader to establish useful parallelisms and contrasts, and thus realize the fallacy and danger of proclaiming that all South Asians are the same or that all Americans are the same" (Priyadarshini 2016, p. 52)

As in O'Brien's short stories, maternity functions prominently in Lahiri's work and it is often the motif of matricentric feminism that allows her characters to gain agency from captivity in domestic spaces. In "Hell-Heaven", from Lahiri's second collection of short stories Unaccustomed Earth (2008), Usha, the adult narrator, provides an account of her mother's romantic liaison with a family friend during the narrator's childhood. Usha's mother, Aparna, at the beginning of the story is a stereotypical Indian immigrant mother and housewife, living in Boston during the late 70s with her scientist husband and her seven-year-old daughter. Aparna's existence is highly circumscribed, both by her gender as well as by the strained relationship with her husband, with whom she has had an arranged marriage and shares very few common interests. Her only form of entertainment involves roaming the streets of Cambridge, Massachusetts, and "looking at discounted house ware" (Lahiri 2008, p. 60) with her daughter Usha after her school-hours. It is during one of these daily walks that Aparna and Usha encounter Pranab Chakraborty, a charismatic Indian graduate student from MIT. Pranab Kaku (Uncle Pranab) as Usha calls him, soon becomes seamlessly integrated with the lives of the narrator's family by "occupying (every night) the fourth chair at our square Formica kitchen table and becoming a part of our family in practice as well as in name" (Lahiri 2008, p. 63). Aparna, thus far crafted as a docile immigrant woman who is unable to come to terms with both her identity and coerced motherhood, undergoes an almost immediate transformation with Pranab's arrival.

From the very first day of interaction between Pranab and Aparna, Aparna assumes the role of the dominant caregiving figure. On the night of their first meeting, Aparna, on becoming aware that Pranab "had not had a proper Bengali meal in three months," invites him over for dinner and also forces him to have "a second dinner." The narrator informs us that Pranab "was from a wealthy family in Calcutta and had never had to do so much as to pour a glass of water." Pranab's incompetence with quotidian domestic tasks as a single graduate student in America makes him almost ready to go back home, save for Aparna's timely intervention. Like Martha in "The Love Object," who recognizes the lack in her lover, Aparna in Hell-Heaven swiftly realizes that Pranab needs a maternal caregiver to tide 
over his "crisis." However, like Martha, Aparna does not have altruistic reasons for assuming this active maternal role. Although she had performed the role of a mother and a housewife dutifully for her own family, the marital and familial bonds are clearly forced. As Usha notes, Aparna's husband "was wedded to his work, his research, and he existed in a shell that neither my mother nor I could penetrate" (p. 65). In contrast, Aparna has with Pranab "all the things she and my father (Aparna's husband) did not have in common: a love of music, film, leftist politics, poetry," and as Usha highlights, "I don't think even my birth made her as happy [as Pranab]" (Lahiri 2008, p. 63).

Unlike Martha, who reassumes an active mothering role in "The Love Object" through her relationship with the lawyer, matricentric feminism functions with a radical difference in Aparna's liaison with Pranab in "Hell-Heaven." Whereas Martha's motives for engaging in an illicit relationship with a married lawyer was clearly to fulfill the actual lack of maternal performances in her life, for Aparna, it is in fact quite the opposite. Aparna's position as an economically dependent immigrant housewife implies that she is more explicitly circumscribed by the norms of patriarchy, as compared to Martha. This is to the extent that even receiving Pranab alone in the house without her daughter or anyone else present is considered as "inappropriate" and as an unstated rule that "went without saying" (p. 64). Aparna's realization that any illicit relationship, beyond the normative ones of a wife and a mother, would definitely invite familial and societal censure is underscored by Usha's comment: "It is clear to me now that my mother was in love with him ... [although] she knew that she could never have him for herself" (Lahiri 2008, p. 67). It is this recognition that forces Aparna to assume the maternal role with Pranab as she is aware that her relationship with Pranab in any other form would not be accepted, by either her husband or (patriarchal) society. As Usha observes: "one might think that he (Aparna's husband) would have felt slightly jealous, or at the very least suspicious about the regularity of Pranab Kaku's visits," but it is the pseudo-maternal relationship between Aparna and Pranab that instead makes her husband "grateful to Pranab Kaku for the companionship he provided" (Lahiri 2008, p. 66). Through "mothering" Pranab, Aparna performs acts of romantic love that she would otherwise be unable to perform within her circumscribed framework as an economically dependent immigrant Indian woman. Her daughter Usha emphasizes how:

Within a few weeks, Pranab Kaku had brought his reel-to-reel over to our apartment, and he played for my mother medley after medley of songs from the Hindi films of their youth. They were cheerful songs of courtship, which transformed the quiet life in our apartment and transported my mother back to the world she'd left behind in order to marry my father... She and Pranab Kaku would argue passionately about these matters, raising their voices in playful combat, confronting each other in a way she and my father never did. (Lahiri 2008, p. 65)

Like Martha, who recognizes in her illicit relationship the potential to break free from societally constructed passive and monolithic womanhood, Aparna locates the possibility of agency in her relationship with Pranab. Vitally, this gaining of matricentric feminist agency shows the dynamic nature of postcolonial feminism, which is also concurrent with a transformation in the character of the domestic space Aparna inhabits. As Usha highlights:

Before we met him (Pranab), I would return from school and find my mother with her purse in her lap and her trench coat on, desperate to escape the apartment where she had spent her day alone. But now I would find her in the kitchen, rolling out dough for luchis, which she normally made only on Sundays for my father and me ... I did not know, back then that Pranab Kaku's visits were what my mother looked forward to all day. (Lahiri 2008, p. 63)

At the beginning of the narrative, Aparna exists in an emotional state of catatonic apathy that is reflected through her perception of the domestic space. The only time Aparna ever leaves the house is when Usha comes back from school, but with Pranab, there is a discernible change in the way Aparna perceives her own house, since now the actions inside the house allow her to express 
her own identity. The home now becomes for Aparna, as bell hooks argues: "a place to regain lost perspective, give life new meaning ... that space where we return for renewal and self-recovery, where we can heal our wounds and become whole" (Hooks 1990). Aparna's assuming of an active role within the domestic space becomes especially important considering the specific role of the "housewife" in colonial and nationalist literature. The housewife was constructed as a passive subaltern figure whose enunciations were disregarded in both historical and literary narratives, which focused on elite perspectives and ignored "the thousands of housewives mostly mothers and wives-who provided indirect support by shouldering family responsibilities" (Kasturi and Mazumdar 1994). The status of these domesticated feminine figures as subalterns was underscored not by their inability to speak, but the failure of their speech to engage in any dialogue with the dominant patriarchal narrative, both literally and figuratively.

This is exemplified through Aparna's position at the beginning of "Hell-Heaven" when her scientist husband considers conversation with her a "chore ... it required an effort which he preferred to expend at the lab" (Lahiri 2008, p. 68). Her only form of interaction with her husband is non-verbal, through the "cereal and tea in the mornings, a cup of tea after he got home, and two different vegetable dishes with dinner" (Lahiri 2008, p. 65). Shyamal's (Aparna's husband) disinterest and refusal to spend any effort in conversing with his wife coupled his propensity to invest that effort "at the lab" is a clear indicator towards his compliance with a traditional patriarchal construct of the housewife: as a commoditized product with a certain use value to be utilized for cooking his food, bearing his children, and looking after them. In direct contrast, with Pranab, Aparna is no longer relegated to being a passive recipient of hegemonic patriarchal oppression as: "Pranab Kaku listened to these (Aparna's) stories with interest, absorbing the vanishing details of her past. He did not turn a deaf ear to her nostalgia, like my father, or listen uncomprehending like me" (Lahiri 2008, p. 66).

Along with the perceptible change in Aparna's character within the domestic space, her relationship with Pranab also leads to a critical difference in the way that her daughter, the narrator, perceives her own mother. Usha the narrator, an American-Indian, born and bred in a far more liberal atmosphere than her mother, initially has an implied tone of condescension towards her mother. This is implicit in Usha's description of her mother in the beginning of the narrative as someone who has "a common Tangail sari ... a thick stem of vermillion powder in the center parting of her hair ... and the full round face and large dark eyes that are so typical of Bengali women" (Lahiri 2008, p. 61). Through Usha's initial description of her mother where she essentializes Aparna as "typical," Lahiri echoes the voice of both the colonial figure who had constructed a monolithic "Indian woman" in their imperial discourses and the native patriarch represented here by Aparna's husband, who has scant respect for Aparna's abilities beyond cooking and child-bearing. Usha's description of her mother at the beginning of the narrative is a direct reflection of the way her mother is perceived by her own husband, Usha's father. With Pranab's arrival, Usha is forced to recognize her mother beyond the stereotype of a typical passive mother and housewife, but as a vibrant individual who has a "love of music, film, leftist politics, poetry" (Lahiri 2008, p. 64). This new-found confidence within the domain of the house allows Aparna to go for "drives through Boston and Cambridge, and soon outside the city, flying down the highway" with Usha and Pranab, which are a radical departure from her earlier excursions that were limited to roaming around houseware shops in Boston. It is pertinent to note here that Lahiri creates in her literary oeuvre the world of the Indian immigrant women during the late 1970s, just a few decades after India had gained independence from the British. Unlike in the twenty-first century where transnational immigration for both genders has become a common occurrence, this was a period when Indians were making their headway into this global phenomenon. Therefore, Aparna's movements in the story are critical due to their symbolic status, as a mobilization of postcolonial femininity and an active interrogation of their liminal position. Aparna's excursions with Pranab connote for the first time a transgression beyond the repressed domestic space into the public sphere where she is not bound up in her status as only a mother or a servile housewife. It is in these public spaces where she "prepared a picnic of hard-boiled eggs and cucumber sandwiches 
and talked fondly (to Pranab) about the winter picnics of her youth" that Aparna is able to explicitly perform an emancipated version of herself. In these external settings, she is able to move beyond the façade that she has to maintain within her own house and reconstruct her own identity as she desires: "Wherever we went, any stranger would have naturally assumed that Pranab Kaku was my father, that my mother was his wife" (Lahiri 2008, p. 67).

As in the "The Love Object" where the lawyer's break up with Martha creates a crisis in her life, in "Hell-Heaven" a similar situation is created in Aparna's life with Pranab embarking on a relationship with an American girl named Deborah. It is pertinent to note here that there was always a latent fear in Aparna that Pranab would soon get involved romantically elsewhere. In fact, in the period preceding Pranab's affair with Deborah, Aparna would often "tease him (Pranab) about women, asking about female Indian students at MIT or showing him pictures of her younger cousins in India" (Lahiri 2008). These attempts by her mother, as the narrator notes, were always predicated by Aparna's prior understanding that "she could never have Pranab Kaku for herself and ... it was her attempt to keep him in the family" (Lahiri 2008, p. 67). For Aparna, Pranab's relationship with Deborah leads Aparna to a temporary crisis and a failed suicide attempt, due to two primary reasons. First, the presence of another woman in Pranab's life deprives Aparna of the possibility of continuing her relationship with Pranab, thereby forcing her to forego the independence she had achieved through this relationship. Second, Deborah now assumes the role of the care giver in Pranab's life, a performance that was strictly within Aparna's domain before Deborah's arrival. Deborah's appropriation of Aparna's role leads to Pranab completely changing from his earlier dynamic with Aparna when he was "totally dependent on her, needing her (Aparna) for those months in a way my father never did in the whole history of their marriage" (ibid.). Aparna is suspicious and distinctly uncomfortable with Deborah's acts of romantic love with Pranab, such as their "feeding each other, allowing their fingers to linger in each other's mouth," since it is a physical manifestation of the maternal love that Aparna had been used to performing with Pranab. Aparna's role as a mother is further threatened through Deborah's arrival, since along with Pranab, the young narrator Usha also starts idolizing Deborah as a maternal figure. As the direct anti-thesis of her own mother, Usha mentions her infatuation with Deborah:

the more my mother began to resent Deborah's visits, the more I began to anticipate them. I fell in love with Deborah, the way young girls fall in love with women who are not their mothers. (Lahiri 2008, p. 69)

Deborah's liberal nature, along with her familiarity with the aspects of American culture that Aparna could never relate to, implies that for the American-born Usha, Deborah becomes an immediate (and better) substitute for her own mother. However, with Deborah's arrival, Aparna adopts a far more assertive maternal role in contrast to her submissive demeanor at the beginning of the narrative. Before her association with Pranab, Aparna's actions as a mother had been predicated largely on the existing constructs and practices equated with "mothers, sisters and aunts in Calcutta." But a marked change takes place in her attitude as a result of Deborah. The first signs of Aparna exercising the agency (that she had gained through mothering Pranab) is exhibited fittingly at Pranab's marriage with Deborah where "she (Aparna) kept speaking in Bengali, complaining about the formality of the proceedings, and the fact that Pranab Kaku, wearing a tuxedo, barely said a word to us because he was too busy leaning over the shoulders of his new American-in-laws." (Lahiri 2008, p. 73). In her ability to articulate her feelings in her native tongue at Pranab's wedding, a practice that she previously used only within the domestic space, it is clear that her matricentric feminist agency has finally found an outlet in the public sphere. Even in her interactions with Usha, Aparna asserts her maternal status by forcing Usha to forego the dance and festivities at Pranab's wedding by saying that "I (Usha) had had plenty of fun already and [she] forced me to put on my coat over my long puff sleeved dress" and leave the party.

This new model of Aparna, as an active maternal figure, continues through the narrator's teenage years as Usha is forbidden by her mother "to attend the dances that were held the last Friday of 
every month in the school cafeteria, and it was an unspoken law that I was not allowed to date" (Lahiri 2008, p. 76). Aparna's inability to gain further agency through Pranab implies that she has to replace Pranab with another figure, through which she could continue her maternal relationship. As a natural consequence, Aparna's lack is fulfilled through her daughter Usha, which in effect consolidates Aparna's role as an actual maternal figure instead of the pseudo-maternal status that she had maintained with her love interest. Concurrently, Aparna's model of motherhood is in a direct dialectic with the liberal maternal figure, which Deborah represents. Usha illustrates this through her assertion that "anyone would have said that Deborah would make an excellent mother, one day. But my mother refused to acknowledge such a thing" (ibid., p. 71). Even Usha's teenage voice of dissent against Aparna's domineering maternal techniques is countered by Aparna's vilifying Deborah:

In the middle of our arguments, she often conjured Deborah as her antithesis, the sort of woman she refused to be. 'If she were your mother, she would let you do whatever you wanted, because she wouldn't care. Is that what you want Usha, a mother who doesn't care? (ibid., p. 77)

Poignantly, it is in Aparna's refusing to be the "sort of woman" and mother that Deborah is and her consequent reactionary stance through which Aparna finds her personal liberated mode of maternity and womanhood. Indeed, this is a model of overlapping personhood unencumbered by patriarchy that refuses to "adopt the binary identity of either 'self' or 'Other', which is offered in dominant theories of identity" (McDowell 1996). Progression beyond these binary classifications of the "Indian woman-self" and the "Immigrant-other" ensues for Aparna through the realization of her multiplicitous identity. This realization allows her to renegotiate the relationships with her husband and daughter on her own terms:

over the years, when I visited, I noticed warmth between my parents that had not been there before, a quiet teasing solidarity, a concern when one of them fell ill. My mother and I had also made peace; she had accepted the fact that I was not only her daughter but a child of America as well... She welcomed my boyfriends into our home and when things didn't work out she told me I would find someone better. After years of being idle she decided, when she turned fifty, to get a degree in library science at a nearby university. (Lahiri 2008)

The story concludes with a vital transition: Aparna is now able to transfer her sense of empowerment to her daughter when a situation similar to Aparna's own experience of her "heart ... broken by a man ... [she] had hoped to marry" (ibid., p. 83) is mirrored in Usha's life.

What distinguishes the protagonists in Lahiri and O'Brien's narratives is the distinct alteration of their own concepts of femininity and womanhood. For both Martha and Aparna, this transformation is not achieved through any external agency, but rather through their own actions and movements within their quotidian domestic spaces. At the beginning of the narratives they exemplify what Deepika Bahri connotes to be the postcolonial, "a word for the margin, an alias for the marginal ... the dematerialized vanishing marginal stripped of reference of history itself" (Bahri 2004). Indeed, peripheral figures who have neither say nor any stake within the dominant dispensations of patriarchal hegemony. Paradoxically, it is this peripheral status of Martha and Aparna that help them recraft their lives. Aparna and Martha's marginalized status allows for a complete detachment from the hegemonic strategies at the center, thereby enabling them to implement feminist tactics unrecognized by patriarchy. By configuring (illicit) motherhood as their tactic of liberation, a feminine role considered passive and non-reactionary by patriarchal hegemony, they deconstruct colonial nations of womanhood that had percolated into masculinist nationalism. As repositories of multiple identities, such as mother, career woman, immigrant national, illicit lovers, amongst others, Aparna and Martha resist the delimitation/classification imposed on the monolithic construct of the "woman" by dominant discourses. Through "exposing the limits of any claim to a singular or autonomous sign of difference" 
(Bhabha 1994), they destabilize stable signifiers of feminine identity, giving rise to the possibilities of multiplicitious, fragmented, and empowered postcolonial selves.

Funding: This research received no external funding.

Conflicts of Interest: The author declares no conflict of interest.

\section{References}

Bahri, Deepika. 2004. Terms of Engagement: Postcolonialism, Transnationalism, and Composition Studies. Crossing Borderlands: Composition and Postcolonial Studies. Edited by Andrea Lunsford and Lahoucine Ouzgane. Pittsburgh: University of Pittsburgh Press.

Banville, John. 2013. Introduction. In The Love Object. London: Faber.

Bhabha, Homi. 1994. The Location of Culture. London: Routledge.

Brah, Avtar. 1996. Cartographies of Diaspora: Contesting Identities. London: Routledge.

Butalia, Urvashi. 1996. Mother India. New Internationalist Magazine, March 5, 277.

Colletta, Lisa, and Maureen O'Connor, eds. 2006. Wild Colonial Girl: Essays on Edna O'Brien. Wisconsin: The University of Wisconsin Press.

Connell, Raewyn W., and James W. Messerschmidt. 2005. Hegemonic Masculinity: Rethinking the Concept. Gender and Society 19: 829-59. [CrossRef]

Crittenden, A. 2010. The Price of Motherhood: Why the Most Important Job in the World Is Still the Least Valued. New York: Picador.

de Certeau, Michel. 2008. The Practice of Everyday Life. Berkeley: University of California Press.

Dowler, Lorraine, and Bonj Szczygiel. 2006. Gender and Landscape: Renegotiating Morality and Space. Edited by Josephine Carubia. London: Routledge.

Francesca, Pellas. 2017. "What Am I Trying to Leave Behind?" An Interview with Jhumpa Lahiri. August 31. Available online: https:/ /lithub.com/what-am-i-trying-to-leave-behind-an-interview-with-jhumpa-lahiri/ (accessed on 1 January 2019).

Giorgio, Adalgisa. 2002. Writing the Mother-Daughter Relationship: Psychoanalysis, Culture and Literary Criticism. In Writing Mothers and Daughters: Renegotiating the Mother in Western European Narratives by Women. New York: Berghahn Books.

Hale, Dorothy J. 2009. Aesthetics and the New Ethics: Theorizing the Novel in the Twenty-First Century. PMLA 124: 896-905. [CrossRef]

Hooks, Bell. 1990. Yearning: Race, Gender and Cultural Politics. Boston: South End Press.

Jackson, Pauline. 1984. Women in 19th Century Irish Emigration. The International Migration Review 18: 1004-20. [CrossRef] [PubMed]

Kasturi, Lila, and Veena Mazumdar. 1994. Women and Indian Nationalism. Centre for Women's Development Studies. Available online: http://www.cwds.ac.in/wp-content/uploads/2016/09/ WomenandIndianNationalism.pdf (accessed on 15 January 2019).

Kelleher, Margaret. 2013. Irish Literary Culture in English. In The Oxford Handbook of Modern Irish History. Edited by Alvin Jackson. Oxford Handbooks Online. [CrossRef]

Kuttainen, Victoria. 2009. Sweet traps: Feminist fantasies of Domestic Confinement on the Cusp of Postcolonial Australia. Australia Studies 1.

Lahiri, Jhumpa. 2008. Unaccustomed Earth. New York: Alfred. A. Knopf.

Lamture, Suman A. 2017. Post-Colonial Dilemmas in the Novels of Jhumpa Lahiri. International Education \& Research Journal 3: 803-5.

Landes, Joan B. 1998. Feminism: The Public and the Private. New York: Oxford University Press.

Lynch, Rachel Jane. 1996. "A Land of Strange, Throttled, Sacrificial Women": Domestic Violence in the Short Fiction of Edna O'Brien. The Canadian Journal of Irish Studies 22: 37-48. [CrossRef]

McDowell, Linda. 1996. Spatializing Feminism: Geographic Perspectives. In Body Space: Destabilizing Geographies of Gender and Sexuality. Edited by Duncan Nancy. London: Routledge.

Murray, Tony. 2013. Edna O'Brien and narrative diaspora space. Irish Studies Review 21: 85-98. [CrossRef]

Nolan, Emer. 2007. Postcolonial Literary Studies, Nationalism, and Feminist Critique in Contemporary Ireland. Éire-Ireland 42: 336-61. [CrossRef] 
Ó Gallchoir, Clíona. 2005. Maria Edgeworth: Women, Enlightenment and Nation. Dublin: UCD.

O’Brien, Dan. 2016. A harp in the hallway: Edna OBrien and Jewish-Irish Whiteness in Zuckerman Unbound. Philip Roth Studies 12: 5-23. [CrossRef]

O’Brien, Edna. 1964. Girls in Their Married Bliss. London: Jonathan Cape.

O'Brien, Edna. 1966. Casualties of Peace. London: Jonathan Cape.

O'Brien, Edna. 1984. A Fanatic Heart: Selected Stories of Edna O'Brien. New York: Farrar Straus Girouz.

O'Brien, Edna. 1996. Down by the River. London: Weidenfeld \& Nicolson.

O'Brien, Edna. 2016. The Little Red Chairs. London: Faber and Faber.

O'Hara, Kiera. 1993. Love Objects: Love and Obsession in the Stories and Edna O'Brien. Studies in Short Fiction 30: 317-25.

O'Reilly, Andrea. 2015. Ain't I a Feminist? Matricentric Feminism, Feminist Mamas, and Why Mothers Need a Feminist Movement/Theory of Their Own. July 1. Available online: https:/ / mommuseum.org/aint-i-a-feministmatricentric-feminism-feminist-mamas-and-why-mothers-need-a-feminist-movementtheory-of-their-own/ (accessed on 1 January 2019).

Pearce, Sandra M. 2006. Edna O'Brien. In Irish Women Writers: An A-to-Z Guide. Edited by Alexander Gonzalez. Westport: Greenwood Press, pp. 268-76.

Pearce, Sandra Manoogian, and Edna O’Brien. 1996. An Interview with Edna O’Brien. The Canadian Journal of Irish Studies 22: 5-8. [CrossRef]

Pelan, Rebecca. 1993. Edna O'Brien's 'Stage-Irish' Persona: An 'Act' of Resistance. The Canadian Journal of Irish Studies 19: 67-78. [CrossRef]

Priyadarshini, N. 2016. Feminism, Womanhood and Motherhood in the Works of Jhumpa Lahiri. International Journal of Interdisciplinary Research in Arts and Humanities 1: 51-57.

Szczygiel, Bonj. 2003. City Beautiful' Revisited, an Analysis of Nineteenth Century Civic Improvement Efforts. Journal of Urban History 29: 107-32. [CrossRef]

Spivak, Gayatri Chakravorty. 1988. Can the subaltern speak? In Marxism and the Interpretation of Culture. Edited by Cary Nelson and Lawrence Grossberg. Urbana: University of Illinois Press, pp. 271-313.

Thapar-Björkert, Suruchi, and Louise Ryan. 2002. Mother India/Mother Ireland: Comparative Gendered Dialogues of Colonialism and Nationalism in the Early 20th Century. Womens Studies International Forum 25: 301-13. [CrossRef]

Wigfall, Clare. 2014. The Love Object Review-Edna O'Brien's Powerful Short Stories. September 21. Available online: https:/ / www.theguardian.com/books/2014/sep/21/the-love-object-review-edna-obrienpowerful-short-stories (accessed on 15 January 2019).

(C) 2019 by the author. Licensee MDPI, Basel, Switzerland. This article is an open access article distributed under the terms and conditions of the Creative Commons Attribution (CC BY) license (http:/ / creativecommons.org/licenses/by/4.0/). 